\title{
PROFIL PSIKOLOGIS ATLET PEKAN OLAHRAGA NASIONAL (PON) PAPUA MENUJU PON XX TAHUN 2020
}

\author{
M. Fadli Dongoran ${ }^{* 1}$, Chyntia Novita Kalalo ${ }^{2}$, Syamsudin ${ }^{3}$ \\ Universitas Musamus, Indonesia ${ }^{1,2,3}$ \\ Email: dongoran_pjkr@unmus.ac.id ${ }^{* 1}$, novita@ unmus.ac.id ${ }^{2}$, syamsudin@ unmus.ac.id ${ }^{3}$
}

Received: 08 February 2020; Accepted 30 April 2020; Published 04 June 2020

Ed 2020; 5(1): 13-21

\begin{abstract}
ABSTRAK
Penelitian ini ditujukan untuk mengidentifikasi profil psikologis atlet PON Papua. Selain itu, pada setiap aspek psikologis atlet PON Papua akan dianalisis kondisi dari masing-masing aspek psikologis berserta penyebaran atlet dan presentasenya. Metode yang digunakan dalam penelitian ini adalah metode survei dengan desain penelitian expost facto. Populasi dalam penelitian ini adalah atlet PON Papua yang akan dipersiapkan menuju PON XX 2020. Teknik pengambilan sampel dalam penelitian ini menggunakan purposive sampling dengan kriteria Atlet PON Papua yang telah melaksanakan pemusatan latihan Provinsi Papua pada tahun 2019. Berdasarkan itu, maka didapat sampel penelitian atlet cabang olahraga yaitu; Handball, Softball, Atletik, Cricket, Futsal, Bolabasket, Pencaksilat yang berjumlah 101 atlet. Pengumpulan data menggunakan kuesioner The Psychological Skills Inventory for Sports (PSIS). Hasil penelitian menunjukan profil psikologis atlet PON Papua menuju PON XX 2020 secara umum berada pada kondisi yang baik.
\end{abstract}

Kata Kunci: Sports Psychology; PON; Papua

\section{PSYCHOLOGICAL PROFILE OF ATHLETE PEKAN OLAHRAGA NASIONAL (PON) PAPUA ROAD TO PON XX 2020}

\begin{abstract}
This study aimed to identify the psychological profile of athletes PON Papua. In addition, each psychological aspect of Athlete PON Papua will be analyzed the condition of each psychological aspect along with the spread of athletes and their presentation. The method used in this study is a survey method with expost facto research design. The population in this study are athletes Papua who will be prepared road to PON XX 2020. The sampling technique used purposive sampling with the criteria for athletes PON Papua who had conducted training camps Papua Province in 2019. Based on that, the research samples obtained from athletes in sports are; Handball, Softball, Athletics, Cricket, Futsal, Basketball, Pencaksilat totaling 101 athletes. Data collection uses the Psychological Skills Inventory for Sports (PSIS) questionnaire. The results showed that the psychological profile of athletes PON Papua road to PON XX 2020 was generally in good condition.
\end{abstract}

Keywords: Sports Psychology; PON; Papua

Copyright $($ C 2020, Journal Sport Area

DOI: https://doi.org/10.25299/sportarea.2020.vol5(1).4621

How To Cite: Dongoran, M.F., Kalalo, C.N., \& Syamsudin. (2020). Profil Psikologis Atlet Pekan Olahraga Nasional (PON) Papua Menuju PON XX Tahun 2020. Journal Sport Area, 5(1), 13-21.

\section{PENDAHULUAN}

Pekan Olahraga Nasional atau disingkat dengan PON merupakan amanat pemerintah melaksanakan UUSKN (pasal 42 dan 43). Dalam UUSKN tersebut juga dijelaskan bahwa setiap pelaksanaan kejuaraan olahraga yang dilaksanakan oleh pemerintah, organisasi, lembaga, maupun masyarakat wajib memperhatikan tujuan 
keolahragaan Nasional dan prinsip penyelenggaraan keolahragaan. Selanjutnya pencapaian prestasi pada ajang tersebut sebagai penjaringan bagi atlet berprestasi dalam meningkatkan harkat dan martabat sebagai individu maupaun Negara di event Internasional.

PON pertama kali terselenggarakan di Solo, pada tahun 1948 dengan mempertandingkan 9 cabang olahraga yang diikuti oleh 600 atlet. PON terus berkembang hingga berevolusi menjadi event olahraga bergengsi dan terbesar di Indonesia. Sampai pada penyelenggaraan PON XIX di Jawa barat, sudah ada 9 Provinsi yang telah menjadi tuan rumah penyelenggaraan. DKI Jakarta merupakan tuan rumah terbanyak dengan 8 kali pergelaran, sekaligus menjadi pemegang rekor juara umum terbanyak berjumlah 11 kali.

Provinsi Papua dalam penyelenggaraan terakhir meraih prestasi terbaik pada peringkat 8 dengan perolehan 17 emas. Artinya prestasi Papua pada Pekan Olahraga Nasional masih belum signifikan, karena belum mampu menembus peringkat 5 besar Nasional. Hal tersebut merupakan sebuah catatan yang harus diperbaiki dan dievaluasi bersama secara komprehensif menuju PON yang akan datang untuk meraih prestasi yang lebih tinggi sekaligus sukses menjadi tuan rumah PON XX.

KONI Papua melalui Kenius Kogoya menargetkan Provinsi Papua pada PON 2020 dapat menembus 5 besar Nasional. Beberapa cabang olahraga tertentu ditargetkan meraih prestasi yang tinggi seperti cabang olahraga beladiri, permainan, terukur, dan beberapa cabang olahraga unggulan lainnya untuk memperoleh 78 mendali emas. Pendekatan pelatihan olahraga melalui pendekatan IPTEK merupakan upaya yang harus dilakukan dalam proses pembinaan olahraga prestasi. Hanya dengan upaya itu yang dapat meningkatkan prestasi kontingen PON Papua, yang selama 15 tahun terakhir selalu gagal menembus 5 besar dalam skala Nasional.

Peningkatan prestasi dalam bidang olahraga merupakan kajian yang sangat kompleks selain membutuhkan sarana dan prasarana yang memadai juga diperlukan pedekatan sports science dukungan ilmu pengetahuan dan teknologi (Iptek) olahraga. Dekan FIK Universitas Negeri Yogyakarta misalnya, dalam sambutan pada seminar International menyatakan bahwa penerapan sports science dalam seluruh rangkaian proses program latihan merupakan langkah kongkret dalam peningkatan prestasi dalam setiap cabang olahraga (Anon, 2018). Selanjutnya sebagai tambahan sports science merupakan ilmu multidisiplin yang mendukung peningkatan performance atlet diantaranya mencakup fisiologi, psikologi, conditioning, dan kedokteran olahraga.

Psikologi olahraga merupakan salah satu yang memiliki peran sentral penerapan sports science dalam olahraga pretasi. Weinberg dan Gould (2011) dalam penelitiannya mengungkapkan keberhasilan dan kegagalan pemain dalam olahraga prestasi sangat ditentukan oleh perpaduan dari kemampuan faktor fisik dan psikologis bahkan untuk cabang olahraga tertentu faktor psikologis tersebut mencapai $80 \%$ sampai $90 \%$. Begitu juga menurut Lutan (2010) bahwa atlet harus memiliki keterampilan psikologis dan moral yang diperlukan oleh cabang olahraga yang ditekuninya untuk berprestasi.

Kompetisi tingkat tinggi seperti Pekan Olahraga Nasional (PON) menuntut kualitas atlet prima bukan hanya dalam segi teknik, fisik, taktik, namun terlebih lagi dalam aspek psikologis. Keempat komponen tersebut secara fungsional saling melengkapi dan menguatkan dalam satu dinamika hubungan yang interaktif. 
Karageorghis dan Terry (2011) menyatakan untuk mendapatkan prestasi yang baik dalam olahraga perlu menggabungkan tiga komponen penting yang menunjang prestasi atlet yaitu kondisi fisik untuk kompetisi, tingkat keterampilan, dan persiapan psikologis untuk bersaing. Kunci perbedaan antara penampilan yang baik dan penampilan yang buruk adalah terletak pada tingkatan keterampilan psikologis pemain yang lebih baik dibandingkan dengan keterampilan fisik. Aspek mental atau psikologis harus mendapatkan porsi latihan yang sama dengan keterampilan fisik, teknik, dan taktik untuk mendapatkan penampilan terbaik atlet.

Paparan di atas diperkuat oleh ketua bidang Sport Science KONI Pusat, Lilik Sudarwati yang mengatakan pentingnya peningkatan faktor mental, ketatnya persaingan jika tidak didukung dengan kematangan mental berpotensi membuat atlet tidak maksimal, sehingga diperlukan persiapan pshychological skills bagi atlet (Septi, 2018). Keterampilan psikologis disebut juga keterampilan mental adalah strategi dan metode sistematis yang sengaja didesain atau disusun untuk peningkatan penampilan atlet dengan kesiapan keterampilan mental dan psikologisnya. Keterampilan mental dalam olahraga kompetitif dirancang untuk menghasilkan kondisi psikologis para atlet yang akan mengarah pada peningkatan performanya. Saat ini, perbedaan pemenang dengan yang kalah dalam olahraga kompetitif presentasinya semangkin tipis. Tidak mengherankan bahwa dalam beberapa tahun terakhir pelatihan keterampilan psikologis telah diakui dan jumlah atlet yang menggunakan strategi pelatihan psikologis untuk meningkatkan penampilannya menjadi sebuah keniscayaan (Birrer \& Morgan, 2010). Dalam kondisi ini keterampilan psikologis akan melekat pada diri atlet sehingga menjadi karakter sebagai profil psikologis yang akan menentukan peran dalam keberhasilan prestasi atlet.

Berbagai kajian di atas menyatakan bahwa peningkatan peforma dalam olahraga dewasa ini merupakan hasil penerapan ilmu pengetahuan dan teknologi yang menempatkan jiwa dan raga manusia menjadi ajang penelitian dalam laboratorium. Informasi baru dari hasil penelitian yang ditemukan perlu dimanfaatkan dan dikembangkan oleh pelatih untuk kepentingan peningkatan proses pelatihan. Apabila pelatih dan KONI Papua akan menerapkan aspek psikologis/mental sebagai bagian penting dalam mempersiapkan para atletnya pada PON 2020, maka perlu kajian ilmiah dan data akurat profil psikologis atlet PON Papua. Profil psikologis adalah aspek-aspek psikologis yang melekat yang menjadi karakter dalam diri atlet dan berpengaruh terhadap kesuksesan dan performa atlet. Dalam cakupan yang lebih spesifik penulis menyatakan bahwa profil psikologis atlet PON Papua menjadi kata kunci dalam upaya persiapan atlet di PON XX Papua tahun 2020.

\section{METODE PENELITIAN}

Metode penelitian mengunakan survei dengan desain penelitian expost facto. Penelitian dilaksanakan pada bulan Oktober s/d November di Kota Jayapura. Pengumpulan data pada lokasi Pemusatan Latihan Daerah (PELATDA) masing-masing cabang olahraga. Populasi yang digunakan dalam penelitian ini adalah atlet PON Papua yang akan dipersiapkan pada PON Papua XX tahun 2020. Teknik pengambilan sampel menggunakan purposive sampling dengan syarat atlet PON Papua yang melaksanakan pemusatan latihan daerah Provinsi Papua pada tahun 2019. Berdasarkan itu, maka diperoleh sampel penelitian atlet pada cabang olahraga; handball, softball, atletik, cricket, futsal, bolabasket, pencaksilat yang berjumlah 101 atlet. 
Teknik pengumpulan data menggunakan instrumen The psychological Skills Inventory for Sport (Mahoney, Gabriel, \& Perkins, 1987). Instrumen telah banyak digunakan dalam mengukur maupun memprediksi penampilan atlet. Instrumen dinyatakan layak dan valid dalam mengukur keterampilan psikologis individu dalam olahraga (Milavic, Padul, Grgantov, Milić, Mannarini, Manzoni, Ardigò, \& Rossi, 2019). Instrumen terlebih dahulu diuji coba dengan tujuan menyeleksi item dan melihat sejauh mana instrumen tersebut dapat mengungkap variabel yang hendak diukur dalam mengumpulkan data pada penelitian sesungguhnya. Kemudian peneliti membuat sebuah kriteria aspek psikologis sebagai acuan menggunakan rumus $\mathrm{Mi}=(\mathrm{ST}+\mathrm{SR}) / 2$ dan SDi $=(\mathrm{ST}-\mathrm{SR}) / 6$ (Wagiran, 2015). Tabel penentuan kriteria dapat dilihat pada tabel 1.

Tabel 1. Rumus Penentuan Kriteria

\begin{tabular}{cc}
\hline Interval & Kondisi \\
\hline di atas $(\mathrm{Mi}+1,8 \mathrm{SD})$ s.d. $(\mathrm{Mi}+3 \mathrm{SD})$ & Sangat Baik \\
\hline di atas $(\mathrm{Mi}+0,6 \mathrm{SD})$ s.d. $(\mathrm{Mi}+1,8 \mathrm{SD})$ & Baik \\
\hline di atas $(\mathrm{Mi}-0,6 \mathrm{SD})$ s.d. $(\mathrm{Mi}+0,6 \mathrm{SD})$ & Cukup Baik \\
\hline di atas $(\mathrm{Mi}-1,8 \mathrm{SD})$ s.d. $(\mathrm{Mi}-0,6 \mathrm{SD})$ & Kurang Baik \\
\hline (Mi - 3SD) s.d. $(\mathrm{Mi}-1,8 \mathrm{SD})$ & Sangat Kurang \\
\hline
\end{tabular}

Berdasarkan rumus penentuan kriteria di atas dicari kriteria setiap aspek psikologis. Profil psikologis berdasarkan masing-masing aspek psikologis atlet diperoleh tabel kriteria aspek psikologis atlet yang disajikan pada tabel 2.

Tabel 2. Kriteria Aspek Psikologis Atlet

\begin{tabular}{lccccc}
\hline \multirow{2}{*}{ Aspek Psikologis } & $\begin{array}{c}\text { Sangat } \\
\text { Baik }\end{array}$ & Baik & $\begin{array}{c}\text { Cukup } \\
\text { Baik }\end{array}$ & $\begin{array}{c}\text { Kurang } \\
\text { Baik }\end{array}$ & $\begin{array}{c}\text { Sangat } \\
\text { Kurang }\end{array}$ \\
\cline { 2 - 6 } Motivasi & $33,59-40$ & $27,2-33,5$ & $20,8-27,2$ & $14,4-20,8$ & $8-14,4$ \\
\hline Percaya Diri & $25,2-30$ & $20,4-25,2$ & $15,6-20,4$ & $10,8-15,6$ & $6-10,8$ \\
\hline $\begin{array}{l}\text { Kontrol } \\
\text { Kecemasan }\end{array}$ & $33,59-40$ & $27,2-33,5$ & $20,8-27,2$ & $14,4-20,8$ & $8-14,4$ \\
\hline Persiapan Mental & $16,81-20$ & $13,6-16,8$ & $10,4-13,6$ & $7,19-10,40$ & $4-7,19$ \\
\hline Pentingnya Tim & $25,2-30$ & $20,4-25,2$ & $15,6-20,4$ & $10,8-15,6$ & $6-10,8$ \\
\hline Konsentrasi & $20,9-27,9$ & $16,9-20,9$ & $13,0-16,9$ & $9,0-13,0$ & $5-9,00$ \\
\hline
\end{tabular}

Data yang diperoleh dianalisis sesuai dengan tabel kriteria sehingga diperoleh kondisi psikologis pada masing-masing atlet PON Papua yang akan dipersiapkan pada PON mendatang untuk lebih jauh diinterprestasikan peneliti.

\section{HASIL DAN PEMBAHASAN}

Profil psikologis adalah aspek-aspek psikologis yang melekat yang menjadi karakter dalam diri atlet dan berpengaruh terhadap kesuksesan dan performa atlet yang terdiri dari aspek; motivasi, kepercayaan diri, konsentrasi, kontrol kecemasan, persiapan mental dan perhatian tim. Dalam cakupan yang lebih spesifik penulis menyatakan profil psikologis atlet PON Papua menjadi kata kunci dalam upaya mempersiapkan atlet PON Papua pada PON ke-XX tahun 2020. Berdasarkan hasil pengumpulan data, diperoleh nilai mean individu atlet PON Papua untuk disesuaikan dengan tabel kriteria aspek psikologis yang sudah ditentukan. Setiap 
individu atlet akan diperoleh hasil kategorinya pada setiap item sehingga akan diketahui frekuensi setiap aspek psikologis yang akan disajikan pada grafik 1.

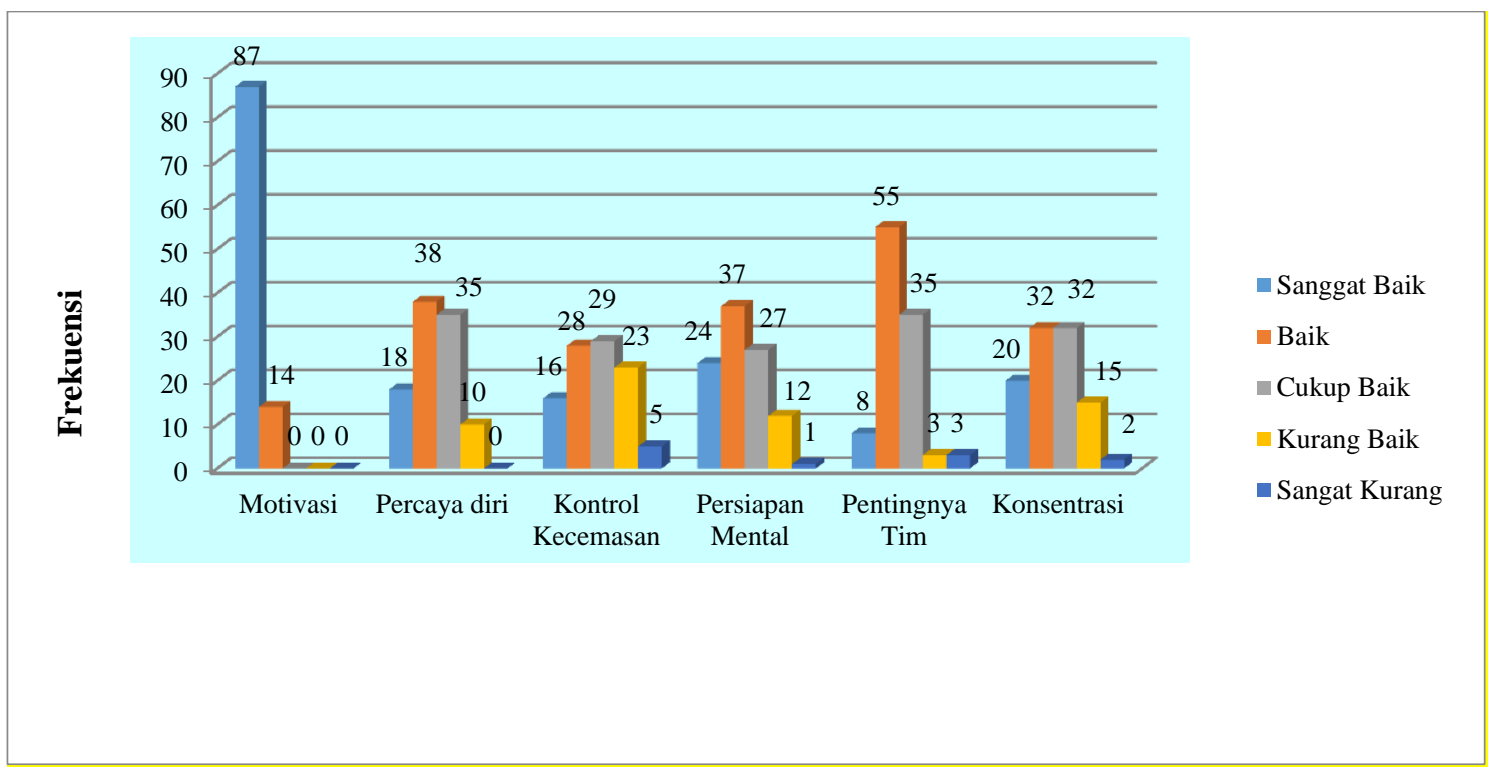

\section{Grafik 1. Profil Psikologis Atlet PON Papua}

Berdasarkan grafik 1, motivasi atlet PON Papua memperoleh nilai mean 33.6 menunjukan kondisi yang "sangat baik". Hasil tersebut tercermin dari 87 atlet dalam kondisi yang sangat baik, dan 14 atlet dalam kondisi baik diperoleh presentase $100 \%$ atlet berada pada garis atas. Sebagaimana motivasi sangat berperan penting terhadap prestasi atlet pada cabang olahraga apapun. Tiga karakteristik atlet renang yang memiliki prestasi tinggi memiliki: (1) motivasi untuk berprestasi, (2) harapan dan (3) optimisme. Karenanya para perenang ini berusaha keras untuk mencapai tujuan yang digerakkan oleh kualitas, dan mereka sangat teliti dan berkomitmen terhadap olahraga mereka. Oleh karena itu, kebutuhan untuk menunjukkan tingkat kompetensi seseorang kepada orang lain tampaknya menjadi sumber motivasi yang kuat untuk atlet elit (Jannah, Mulyana, \& Muthohir, 2015). Temuan ini juga sejalan dengan beberapa penelitian dimana motivasi berkotribusi terhadap prestasi atlet (Muskanan, 2015; Rahayu \& Mulyana, 2015). Atlet dengan motivasi yang sangat baik akan bekerja keras dalam menyelesaikan tugas, memiliki kedisiplinan dalam latihan, serta tidak bergantung pada orang lain, mempunyai kematangan pada kepribadiannya. Hasil ini merupakan catatan yang harus terus dijaga oleh seluruh manajeman maupun seluruh atlet.

Kepercayaan diri atlet PON Papua menunjukan kondisi yang baik dengan rincian frekuensi 18 atlet pada kondisi sangat baik, 38 atlet pada kondisi baik, 35 atlet kondisi cukup baik, 10 atlet pada kondisi kurang baik, dan tidak ada atlet pada kondisi sangat kurang. Sehingga dengan jumlah presentase $55.4 \%$ atlet berada pada garis atas. Menurut Weinberg dan Gould (2011) bahwa individu yang memiliki rasa percaya diri yang tinggi akan lebih mudah mengendalikan dirinya dalam keadaan seperti apapun, tenang dalam melakukan sebuah tindakan, dan lebih mudah memusatkan perhatian. Lebih lanjut dijelaskan bahwa individu cenderung mengarahkan tindakanya pada tujuan yang cukup menantang, dan tidak mudah frustasi dalam mencapai cita-citanya. Salah satu temuan yang paling konsisten dalam literatur penampilan puncak adalah korelasi langsung 
antara tingginya tingkat kepercayaan diri dan performa olahraga yang sukses. Sebaliknya terdapat 10 atlet dengan presentase 9\% dalam kondisi yang kurang baik.

Kontrol kecemasan dan konsentrasi Atlet PON Papua memperoleh nilai terendah, keduanya berada dalam kondisi "cukup baik. Kontrol kecemasan adalah kemampuan atlet untuk mengendalikan perasaan cemas baik dari dalam diri atlet maupun dari lingkungan yang dihadapinya untuk tidak terlalu merasakan cemas yang berlebih sehingga dapat dikelola dan dimanfaatkan sebagai alarm kewaspadaan pada atlet dan meningkatkan penampilan atlet. Dapat dilihat pada aspek kontrol kecemasan frekuensi atlet dalam kondisi kurang baik berjumlah 23 atlet, dan 5 atlet dalam kondisi sangat kurang. Diperoleh sebesar $28 \%$ atlet dalam kondisi digaris bawah. Identifikasi instrumen menunjukan sejumlah atlet merasakan competitive state anxiety yaitu kecemasan yang timbul karena situasi spesifik yang merupakan respon atas situasi persaingan yang mengancam dalam pertandingan atau turnamen yang akan dihadapi.

Sedangkan pada aspek konsentrasi frekuensi atlet dalam kondisi kurang baik berjumlah 15 atlet dan 2 atlet dalam kondisi sangat kurang. Presentase sebesar 16.8\% atlet berkontribusi pada garis bawah. Konsentrasi diartikan sebagai perhatian yang terpusat terhadap suatu objek untuk jangka waktu tertentu. Atlet yang fokus dengan konsentrasi penuh pada tugas dan tidak terganggu dan terpengaruhi oleh stimulus yang besifat eksternal maupun internal (Komarudin, 2015).

Persiapan mental dengan nilai mean 14.07 berada dalam kondisi "baik". Frekuensi atlet dalam kondisi sangat baik berjumlah 24 atlet, dan 37 atlet dalam kondisi baik. Diperoleh presentase sebesar $60.4 \%$ atlet berada pada garis atas. Namun perlu diperhatikan, ada presentase sebesar $13 \%$ atlet berada pada garis bawah. Persiapan mental merupakan perencanaan atlet dalam semua aspek kognitif, emosi, dan perilaku yang digunakan untuk memperoleh performance serta kesiapan psikologis yang optimal dalam kompetisi dan latihan. Persiapan mental penting dilakukan sebelum, selama, dan sesudah menghadapi kompetisi. Perencanaan mental yang digunakan sebelum kompetisi dapat mengoptimalkan kesiapan psikologis (kepercayaan diri, kontrol diri, konsentrasi) dan regulasi emosi (kecemasan, arousal, agresi). Hasil penelitian menyatakan bahwa ada pengaruh yang signifikan antara latihan mental terhadap peningkatan penampilan atlet (Kar \& Bhukar, 2013). Lebih lanjut, latihan mental (imagery, goal setting, self-talk, and relaxation) efektif untuk keberhasilan atlet (Sadeghi, Omar-Fauzee, Jamalis, AbLatif, \& Cheric, 2010). Selanjutnya 44 persen atlet menjelaskan bahwa performa ditentukan oleh penerapan strategi dan teknik persiapan mental (Komarudin, 2015). Persiapan mental tidak hanya penting untuk penampilan pada saat kompetisi tetapi sama pentingnya untuk latihan.

Pentingnya tim dengan memperoleh nilai mean 21.5 berada pada kondisi "baik." Frekuensi atlet dalam kondisi sangat baik berjumlah 8 atlet, dan 55 atlet pada kondisi baik. Diperoleh presentase sebesar $62.4 \%$ atlet berada pada garis atas. Pada dasarnya setiap atlet merupakan anggota dari suatu perkumpulan olahraga tertentu yang secara rutin melalukan kegiatan latihan dan pertandingan. Dalam tim inilah setiap atlet memperoleh pengalaman-pengalaman baik pengetahuan maupun keterampilan olahraga. Ketika membicarakan tentang tim maka tidak dapat dipisahkan dengan pentingnya tim. Tim adalah kelompok orang yang harus berkomunikasi satu anggota dengan anggota lainnya untuk memperoleh tujuan bersama yang ditetapkan (Weinberg \& Gould, 2011). Pentingnya tim dalam tulisan ini adalah suatu tindakan yang dilakukan oleh atlet dimana 
mengutamakan proses kesatuan dan kebersamaan sehingga memungkinkan tim dapat bekerja dengan baik dan efektif.

Luasnya tuntutan fisik dan mental dari olahraga prestasi niscaya atlet untuk lebih memahami profil psikologisnya menuju PON XX 2020. Arthur, Callow, Roberts, dan Glendinning (2019) dalam penelitiannya telah mengembangkan keterampilan pelatih dalam peningkatan keterampilan psikologis atlet. Bukan hanya terfokus kepada atlet, pelatih harus memiliki berbagai keterampilan mengembangkan dan meningkatkan keterampilan psikologis atlet untuk memperoleh hasil yang maksimal dalam kompetisi. Hasil menunjukan secara umum atlet dengan kondisi psikologis yang baik, namun beberapa aspek masih dalam kondisi yang kurang baik seperti aspek kontrol kecemasan dan konsentrasi yang memiiki presentase $28 \%$ dan $16.8 \%$ pada garis bawah, begitu juga $12.8 \%$ pada aspek persiapan mental. Garis bawah yang dimaksud dalam penelitian ini menunjukan kondisi antara kurang baik dan sangat kurang, sedangkan garis atas menujukan kondisi antara sangat baik dan baik. Ini harus menjadi fokus perhatian seluruh stakeholder yang membantu peningkatan prestasi atlet terlebih lagi bagi pelatih. Hasil ini dapat menjadi gambaran sekaligus juga masukan kepada pelatih mengetahui profil psikologis atlet PON Papua untuk sebaiknya diberikan intervensi yang dapat meningkatkan profil psikologis atlet. Persiapan menuju PON XX 2020 memerlukan intervensi psikologis sesuai dengan kebutuhan atlet yang akan berdampak positif pada penampilannya. Selain itu, untuk menjadi perhatian bagi seluruh sektor dalam lingkungan atlet untuk memenuhi kebutuhan dasar psikologis atlet sebagai dasar pengembagan psikologis atlet (Bedir, Erhan, Sen, Bedir, \& Yazici, 2018). Berbagai penelitian menujukan akan pentingnya aspek psikologis atlet terhadap peningkatan prestasi dan penampilan dengan intervensi psikologis tertentu (Setyawati, 2014; Zakrajsek \& Blanton, 2017; Kahrovic, Radenkovic, Mavric, \& Muric, 2014).

\section{KESIMPULAN}

Profil psikologis atlet PON Papua menuju PON XX 2020 secara umum berada dalam kondisi yang baik. Motivasi merupakan aspek psikologis tertinggi dengan kondisi sangat baik dengan presentase $100 \%$ berada pada garis atas. Kepercayaan diri, persiapan mental, dan pentingnya tim pada kondisi baik masing-masing memiliki presentase $55.4 \%, 60.4 \%$, dan $62.4 \%$ berada pada garis atas. Sedangkan profil psikologis terendah pada aspek kontrol kecemasan dan konsentrasi dengan kondisi cukup baik yang memiliki presentase masing-masing $43.5 \%$ dan $52 \%$ berada pada garis atas, sedangkan $28 \%$ dan $16.8 \%$ atlet pada garis bawah. Sehingga hasil ini menjadi perhatian yang cukup serius bagi seluruh stakeholder yang akan mensukseskan PON Papua sebagai tuan rumah maupun meraih prestasi yang gemilang pada tahun 2020 .

\section{DAFTAR PUSTAKA}

Anon. (2018). Inovasi Sports Science Untuk Meningkatkan Prestasi Olahraga. www.uny.ac.id." Retrieved February 2020 (Https://Www.Uny.Ac.Id/Berita/Inovasi-Sports-Science-Untuk-MeningkatkanPrestasi-Olahraga). 
Arthur, R. A., Callow, N., Roberts, R., \& Glendinning, F. (2019). Coaches coaching psychological skills-why not? A framework and questionnaire development. Journal of Sport and Exercise Psychology, 41(1), 10-23. https://doi.org/10.1123/JSEP.2017-0198

Bedir, D., Erhan, E., Sen, I., Bedir, F., \& Yazici, A. G. (2018). The Effects of Basic Psychological Needs on Psychological Skills of Athletes. European Journal of Physical Education and Sport Science, 3(10), 356-366.

Birrer, D., \& Morgan, G. (2010). Psychological skills training as a way to enhance an athlete's performance in high-intensity sports. Scandinavian Journal of Medicine \& Science in Sports. 20, 78-87.. https://doi.org/10.1111/j.1600-0838.2010.01188.x

Jannah, M., Mulyana, O. P., \& Muthohir, T. C. (2015). Psychological Profiles of Indonesian Elite Swimmers. Malaysian Journal of Movement, Health \& Exercise, 4(2), 31-36. https://doi.org/10.15282/mohe.v4i2.37.

Kahrovic, I., Radenkovic, O., Mavric, F., \& Muric, B. (2014). Effects of the self-talk strategy in the mental training of athletes. Physical Education and Sport, 12(1), $51-58$.

Kar, R., \& Bhukar, J. A. I. P. (2013). Effect of Mental Training on Track \& Field Performance and Mental Skills-A Single Subject Design. Academic Sports Scholar, 2(1), 1-7.

Karageorghis, C. I., \& Terry, P. C. (2011). Inside sport psychology. Human Kinetics Champaign, IL.

Komarudin, M. (2015). Psikologi Olahraga. Bandung: PT Remaja Rosdakarya.

Lutan, R. (2010). Modul Mata Kuliah Sejarah dan Filsafat Olahraga. Bandung: FPOK UPI.

Mahoney, M. J., Gabriel, T. J., \& Perkins, T. S. (1987). Psychological skills and exceptional athletic performance. The Sport Psychologist, 1(3), 181-199. https://doi.org/10.1123/tsp.1.3.181.

Milavic, B., Padulo, J., Grgantov, Z., Milić, M., Mannarini, S., Manzoni, G. M., ... Rossi, A. (2019). Development and factorial validity of the Psychological Skills Inventory for Sports, Youth Version-Short Form: Assessment of the psychometric properties. PLoS ONE, 14(8), 1-17. https://doi.org/10.1371/journal.pone.0220930

Muskanan, K. (2015). Analisis Motivasi Berprestasi Atlet Pusat Pendidikan dan Latihan Olahraga Pelajar ( PPLP ) Provinsi Nusa Tenggara Timur. Jurnal Kebijakan \& Administrasi Publik, 19(2), 105-113. https://doi.org/10.22146/jkap.7608. 
Rahayu, E., \& Mulyana, O. P. (2015). Hubungan antara Goal-Setting dan Motivasi Berprestasi dengan Prestasi Atlet Renang. Character: Jurnal Penelitian Psikologi., $3(2), 1-5$.

Sadeghi, H., Omar-Fauzee, M.-S., Jamalis, M., Ab-Latif, R., \& Cheric, M. C. (2010). The Mental Skills Training of University Soccer Players. International Education Studies, 3(2), 81-90. https://doi.org/10.5539/ies.v3n2p81

Septi, A. D. (2018). Elang Asian Games, Peningkatan Mental Atlet Jadi Perhatian. Detiksport. Retrieved August 28, 2018 (Https://Sport.Detik.Com/Read/2018/07/06/032904/4100833/82/Jelang-AsianGames-Peningkatan-Mental-Atlet-Jadi-Perhatian).

Setyawati, H. (2014). Stratregi intervensi peningkatan rasa percaya diri melalui imagery training pada atlet Wushu Jawa Tengah. Journal of Physical Education, Health and Sport, 1(1), 48-59. https://doi.org/10.15294/jpehs.v1i1.3012.

Wagiran. (2015). Metodologi Penelitian Pendidikan. Yogyakarta: Deepublish.

Weinberg, R. S., \& Gould, D. (2011). Foundations of Sport and Exercise Psychology: Welcome to Sport and Exercise Psychology; Chapter 2. Personality a Sport; Chapter 3. Motivation; Chapter 4. Arousal, Stress, and Anxiety; Chapter 5. Competition and Cooperation; Chapter 6. Feedback, Reinforcem. Human Kinetics.

Zakrajsek, R. A., \& Blanton, J. E. (2017). Evaluation of psychological interventions in sport and exercise settings. In Oxford research encyclopedia of psychology (pp. 136). USA: Oxford University Press USA. https://doi.org/DOI: 10.1093/acrefore/9780190236557.013.223. 